\title{
Promoting undergraduates' awareness of the importance of thinking critically about false or inaccurate scientific information presented in news articles
}

\author{
Pablo Antonio Archila \\ School of Education, Universidad de los Andes,Bogotá,Colombia.pa.archila@uniandes.edu.co \\ ORCID: bttp:/ / orcid.org/0000-0003-0225-4701 \\ Jorge Molina \\ Department of Biological Sciences, Universidad de los Andes, Bogotá, Colombia.jmolina@uniandes.edu.co \\ ORCID: bttps:// orcid.org/0000-0003-3018-6726 \\ Anne-Marie Truscott de Mejía \\ School of Education, Universidad de los Andes,Bogotá, Colombia.atruscot@uniandes.edu.co \\ ORCID: bttps:/ / orcid.org/0000-0002-8380-8173
}

[Recibido: 7 Febrero 2019. Revisado: 14 Mayo 2019. Aceptado: 12 Julio 2019]

\begin{abstract}
Being aware of the importance of thinking critically about wrong scientific information presented in news articles is an important form of scientific media literacy. However, little is known about how undergraduates evaluate wrong scientific information presented in news articles. This article discusses the effect of a teaching-learning sequence (TLS) in promoting students' awareness of the importance of thinking critically about false or inaccurate scientific information presented in news articles. It examines the written and oral arguments produced by 141 university students (73 females and 68 males, 16-22 years old) in Colombia during a complete TLS supervised by the same instructor. The data used in this analysis was collected from students' written responses, and audio and video recordings. The first aim of this investigation was to provide evidence of how undergraduates evaluate wrong scientific information presented in news articles when purposely no definition of misleading information is given. The second was to assess the effectiveness of the TLS in promoting students' awareness of the importance of thinking critically about wrong scientific information presented in news articles. The findings show that not all participants perceived misleading information in the same way, and students usually over-estimate the truth or certainty that can be attributed to scientific information communicated in news articles.
\end{abstract}

Keywords: Critical thinking, false scientific information, inaccurate scientific information, news articles, scientific media literacy, university science education.

Promoción de la conciencia de los estudiantes de pregrado sobre la importancia de pensar críticamente acerca de la información científica falsa o inexacta presentada en artículos de prensa

Resumen: Un aspecto de la alfabetización mediática en ciencias tiene que ver con ser consciente de la importancia de pensar críticamente acerca de la información científica errónea presentada en artículos de prensa. Empero, poco se conoce sobre cómo los estudiantes de pregrado evalúan este tipo de información. En este artículo se discute el efecto de una secuencia de enseñanza-aprendizaje (TLS, por sus siglas en inglés) a la hora de concientizar a los estudiantes sobre la importancia de pensar críticamente acerca de información científica falsa o inexacta presentada en artículos de prensa. El artículo examina los argumentos escritos y orales de 141 estudiantes universitarios (73 mujeres y 68 hombres, entre 16 y 22 años de edad) en Colombia, durante una TLS supervisada por el mismo profesor. Los datos empleados para este análisis fueron tomados de las respuestas escritas de los estudiantes y registros de audio y video. El primer objetivo de esta investigación fue proveer evidencia de cómo estudiantes de pregrado evalúan información científica errónea presentada en artículos de prensa cuando no se les brinda deliberadamente una definición de información engañosa. El segundo objetivo fue evaluar la efectividad de la TLS al momento de concientizar a los estudiantes sobre la importancia de pensar críticamente acerca de información científica errónea presentada en artículos de prensa. Los resultados muestran que no todos los participantes percibieron la información engañosa del mismo modo. También se encontró que los estudiantes usualmente sobrestiman la verdad o la certeza que se puede atribuir a la información científica comunicada en artículos de prensa. 
Palabras clave: Pensamiento crítico, información científica falsa, información científica inexacta, artículos de prensa, alfabetización mediática en ciencias, educación científica universitaria.

Para citar este artículo: Archila, P.A., Molina, J. y Truscott de Mejía, A.M (2019) Promoting undergraduates' awareness of the importance of thinking critically about false or inaccurate scientific information presented in news articles. Revista Eureka sobre Enseñanza y Divulgación de las Ciencias 16(3), 3106. doi: 10.25267/Rev_Eureka_ensen_divulg_cienc.2019.v16.i3.3106

\section{Critical thinking and argumentation in higher science education}

There is, as yet, no consensus on the definition of the notion of critical thinking and multiple perspectives are available (Hitchcock 2017). In contrast, there is considerable degree of consensus in the literature on the view that critical thinking involves argumentation (e.g. Andrews 2015; Archila 2018; Jiménez-Aleixandre and Puig 2012). In this study, critical thinking was understood as "reasonable reflective thinking focused on deciding what to believe or do" (Ennis 2015, p. 32). According to Ennis (2015), (1) analyzing arguments, (2) being well informed, and (3) judging the credibility of a source, are some of the desirable actions of critical thinkers in the twenty-first century. The current study followed these three desirable actions of critical thinkers. Consequently, we based our work in the premise that students' argumentation is crucial to promoting their awareness of the importance of thinking critically.

Clearly, focusing on students' argumentation is only one possibility, among others, to engage them in critical thinking practices, discussing and evaluating scientific information presented in news articles. For example, in The Palgrave Handbook of Critical Thinking in Higher Education (Davies and Barnett 2015), some scholars highlight the critical thinking dispositions across a range of habits of mind, such as willingness to think critically (Hamby 2015), openmindedness (Davies and Barnett 2015), intellectual perseverance (Bailin and Battersby 2015), and respect for alternative viewpoints (Barnett 2015), as important aspects to be considered in educational practices interested in provide students with opportunities to think critically in university courses.

Other aspects to bear in mind have to do with willingness to seek or be guided by reason (Bailin and Battersby 2015), tolerance of ambiguity (Jones 2015), metacognition (Lau 2015), desire to be well-informed (Bailin and Battersby 2015), cultural variance (Chirgwin and Huijser 2015), and self-regulation (Bailin and Battersby 2015; Jones 2015). These aspects offer an idea of the complexities behind the preparation of critical thinkers. As Andrews (2015) and Wendland, Robinson, and Williams (2015) remind us, the idea of promoting critical thinking in university courses is only now emerging and therefore there is still much work to be done. For this reason, we delimited our study to one aspect: argumentation. And we proposed a realistic and moderate aim: to promote students' awareness of the importance of thinking critically about wrong scientific information presented in news articles.

According to Archila (2018), critical thinking is relevant to scientists when they make decisions in their practice, such as how to evaluate the advantages and disadvantages of a method and explore different routes to scientific knowledge. Moreover, recent literature corroborates the importance of promoting this notion in science education (e.g. McLaughlin and McGill 2017; Tiruneh, De Cock, Weldeslassie, Elen, and Janssen 2017). It may be obvious to point out that higher education institutions are aware of the importance of critical thinking. Nonetheless, Ding, Wei, and Liu (2016) maintain that university science departments spend little empirical effort considering how to promote university students' awareness of the importance of thinking critically within their courses. 
Critical thinking is socially beneficial. It plays a key role not only in scientific practice, but also with regard to the problems and issues citizens encounter in everyday life (Girle 2011; Kahane 1989). This is the reason why in higher education institutions, the promotion of awareness of the importance of critical thinking has gradually become a priority (Andrews 2015; Hepworth and Duvigneau 2013; Sheffield Jr. 2018). However, Golding (2011) and Wendland et al. (2015) maintain that traditional classroom pedagogy (instructor-centered orientation) is one of the biggest obstacles to the enhancing of undergraduates' critical thinking processes. These authors consider that dogmatism should be replaced by activities involving planned classroom debates as a way of helping students to construct well-reasoned, informed, and nuanced opinions. Clearly, students' argumentation is crucial for enriching the views addressed in these debates. It should be pointed out that several scholars assert that argumentation contributes to critical thinking and vice versa (e.g. Andrews 2015; Jiménez-Aleixandre and Puig 2012). In other words, "argumentation implies criticality; the one cannot function without the other" (Andrews 2015, p. 60).

In science teaching and learning, engaging in argumentation implies the critical evaluation of scientific claims (Archila 2012, 2016). Christenson, Gericke, and Chang Rundgren (2017) consider that there are two main types of argumentation that should be promoted in science education: (1) argumentation on scientific issues and (2) argumentation on socio-scientific issues. For these authors, critical thinking is expected in both cases. Recently, Muller Mirza (2015) stressed that argumentative interaction can be considered as a potential means of constructing knowledge in higher education. Additionally, Archila (2017) offered evidence to support the claim that small-group debate and whole-class debate are desirable and legitimate ways to engage university science students in argumentative interaction.

Rose (2016) asserts that thought-provoking questions are the basis for promoting students' awareness of the importance of critical thinking. Similarly, Archila (2017) considers that asking and addressing this type of questions is a necessary condition for creating university science classroom debates. For this author, a thought-provoking question such as: "are scientists responsible for the way their own work is used by others?" creates a scenario in which the instructor can provide students with opportunities to make decisions, argue, and become aware of the importance of thinking critically about the given question. At the tertiary science education level in particular, the thought-provoking question should have two main challenges: (1) high-level scientific content complexity, and (2) high-level cognitive processing (argumentative and critical thinking skills). Thus, the work of the instructor is to integrate these challenges in one question and find a balance between them when planning a course.

\section{Scientific media literacy}

In the current study, the concept "scientific media literacy" refers to the combination of scientific literacy with media literacy (Belova and Eilks 2016; Chang Rundgren and Rundgren 2014). According to McClune and Jarman (2010), "the primary purpose of media is not to educate, rather to inform, interpret, persuade, frequently to entertain, and, crucially, to make profit for its proprietors or at least to ensure economic viability" (p. 748). Additionally, Butler (2015) maintains that consumers of information must be aware of the importance of thinking critically about false or inaccurate content presented in mass media.

The use of science in the news media as a source of classroom strategies designed to engage students in critical thinking activities is not new (e.g. Jarman and McClune 2007; McClune and Jarman 2011; Oliveras, Márquez, and Sanmartí 2013, 2014; Thier 2008). However, the majority of strategies have been tested at primary (6-10 years old), middle (11-14 years old), and high school (15-18 years old) level. That is the reason why little is known about their effects at 
university level (Mysliwiec, Shibley, and Dunbar 2004). Also, very little research has been directed toward an important matter relevant to that aim, namely, how undergraduates evaluate wrong scientific information presented in news articles (Lin 2014).

No other medium of mass communication covers as much scientific information as do news articles. However, as a precautionary reminder, citizens must bear in mind news articles typically do not provide deep explanations of the scientific procedure used and do not communicate the details of scientific practice (Shea 2015). Additionally, in some cases, news articles are a translation from the language (e.g. English, French) used in a primary source in the language (e.g. Spanish, Japanese) of the readers. Clearly, a bad translation or interpretation can be the cause of false or inaccurate information (Amano, González-Varo, and Sutherland 2016; Rapp 2016). Naturally, the situation becomes more complicated when the person who writes the news article has no scientific background or training. Thus, the scientific media literate individual usually reads the primary source as a way of verifying the information presented in a translated news article. Arguably, not having a desirable reading level of proficiency in the language of the primary source could prove an obstacle (Amano et al. 2016; Archila and Truscott de Mejía 2017).

The focus of the current study is on false or inaccurate scientific information presented in news articles. However, it is important to bear in mind that there are many other ways in which media information can be misleading. For example (1) de-emphasizing important details (Hastak and Mazis 2011). This can include information about uncertainty of the outcomes and possible alternative explanations of the phenomenon. (2) Exaggerating the effectiveness of a technology that is just emerging (Hastak and Mazis 2011), and (3) framing the information in a certain way. This last situation is well documented by Carver, Wiese, and Breivik (2014). These researchers proposed a teaching program that helped them teach thirtyfour upper secondary school biology students how to identify gene frames in newspaper texts as a way to promote media literacy and learning in genetics education. Carver et al. (2014) chose news stories from both tabloid and broadsheet (elite) newspapers. Most importantly, this program helped students identify frames in articles with a high degree of accuracy.

In science education, critical reading is considered a branch of critical thinking (Lin 2014; McClune 2017; McClune and Jarman 2011; Oliveras et al. 2014). In other words, providing students with opportunities to become aware of the importance of reading critically texts with scientific content contributes to promoting their awareness of the importance of thinking critically. In the current study, critical reading is considered as the ability to evaluate the reliability of new information presented in a written text by comparing it to what the reader already knows and to information from other sources (e.g. primary sources), and determining whether claims made in the text are justified by evidence and explained by reasonable explanations (McClune and Jarman 2011).

False or inaccurate scientific information presented in news articles may lead to misinformation (Bedford 2010; Legates, Soon, Briggs, and Monckton of Brenchley 2015). Similarly, Rapp (2016) maintains that reading false or inaccurate information is an obstacle to making informed decisions in everyday life. In science classrooms, the problem is that students usually over-estimate the truth or certainty that can be attributed to scientific information communicated in news articles (McClune and Jarman 2010). Thus, higher education institutions should encourage their instructors to create instructional methods aimed at helping students to become aware of the importance of thinking critically about false or inaccurate scientific information presented in news articles. In the present article, we propose a teaching-learning sequence (TLS) that we consider would contribute to promote 
university students' awareness of the importance of thinking critically about false or inaccurate scientific information presented in news articles.

\section{Aims and significance of the study}

Our study sought to provide evidence of how undergraduates evaluate wrong scientific information presented in news articles when purposely no definition of misleading information is given. In addition, we intended to assess the effectiveness of the TLS in promoting students' awareness of the importance of thinking critically about wrong scientific information presented in news articles. The significance of the present study is that it expands on the scope of some notable work carried out previously that has focused on the use of science in the news media as a source of classroom strategies designed to promote students' awareness of the importance of thinking critically at primary, middle, and high school level. As such, the research questions that guided this exploratory investigation were:

(1) How did a group of university students evaluate wrong scientific information presented in news articles when purposely no definition of misleading information is given?

(2) How well did the TLS promote a group of university students' awareness of the importance of thinking critically about wrong scientific information presented in news articles?

\section{The teaching-learning sequence proposed in this study}

In this study, the term teaching-learning sequence (TLS) refers to the articulation between proposed teaching and expected student learning as a distinguishing feature of such research inspired subject-oriented sequences (Psillos and Kariotoglou 2016). In science classrooms, the use of TLS has produced promising results. A TLS is both an interventional research activity and a product (Psillos and Kariotoglou 2016). According to Psillos and Kariotoglou (2016) a TLS can be one session class or few weeks long. The TLS proposed in this study was designed as a single 80 -minute class session.

The proposed TLS consists of four steps (Table 1) and has four main characteristics: (1) it provides undergraduates with opportunities to make decisions about a thought-provoking question related to false or inaccurate scientific information presented in four excerpts from three news articles; (2) at each step, undergraduates have the opportunity to enrich the positions they use to argue in favor of their decision; (3) they can change the decision if and whenever they want to; and most importantly, (4) each step has been designed to consistently engage university students in critical thinking. 
Table 1. The teaching-learning sequence proposed in this study.

\begin{tabular}{|c|c|c|c|}
\hline Step & Activity & Details & Didactic Purpose \\
\hline 1 & $\begin{array}{l}\text { Questionnaire, Part } \\
\text { One: Making an } \\
\text { initial decision }\end{array}$ & $\begin{array}{l}\text { The undergraduates read four } \\
\text { excerpts of three news articles } \\
\text { related to science. The false or } \\
\text { inaccurate scientific information } \\
\text { appears in bold. Also, the reason } \\
\text { why it is false or inaccurate is } \\
\text { provided at the end of each } \\
\text { news article. } \\
\text { Each undergraduate uses the text } \\
\text { provided to make a decision } \\
\text { about the question, "Which } \\
\text { excerpt is misleading?" }\end{array}$ & $\begin{array}{l}\text { The didactic purpose of Part One of the } \\
\text { questionnaire is to encourage each undergraduate } \\
\text { to make an initial decision (before debating) and } \\
\text { think critically about false or inaccurate scientific } \\
\text { information presented in the four excerpts. } \\
\text { The instructor introduces the class to the context } \\
\text { of each news article. The excerpts offer } \\
\text { undergraduates the opportunity to familiarize } \\
\text { themselves with the false or inaccurate scientific } \\
\text { information presented in the news articles. } \\
\text { The question posed to each student ("Which } \\
\text { excerpt is misleading?”) has several possible } \\
\text { answers: (a) None, (b) One of the four excerpts: } \\
\text { which one? (c) Two of the four excerpts: which } \\
\text { two? (d) Three of the four excerpts: which three? } \\
\text { (e) All four excerpts. Why did you make this } \\
\text { decision? }\end{array}$ \\
\hline 2 & $\begin{array}{l}\text { Making a group } \\
\text { decision: Small-group } \\
\text { debate }\end{array}$ & $\begin{array}{l}\text { The undergraduates are organized } \\
\text { in groups of three to discuss the } \\
\text { decision made by each } \\
\text { undergraduate in Step } 1 \text { with a } \\
\text { view to making a group } \\
\text { decision. }\end{array}$ & $\begin{array}{l}\text { The discussion among undergraduates enables } \\
\text { them to learn about the decision made by each } \\
\text { group member in Step } 1 . \text { Students' critical } \\
\text { thinking about false or inaccurate scientific } \\
\text { information presented in the news articles is } \\
\text { crucial to the discussion. } \\
\text { Making a group decision constitutes a challenge } \\
\text { that will motivate students' argumentation during } \\
\text { this step which involves deliberation. }\end{array}$ \\
\hline 3 & Whole-class debate & $\begin{array}{l}\text { The entire class debates ("Which } \\
\text { excerpt is misleading?"), } \\
\text { taking into account the } \\
\text { decisions made by each group } \\
\text { in Step } 2 \text {. } \\
\text { Each group announces its decision } \\
\text { to the class and presents the } \\
\text { underlying arguments. }\end{array}$ & $\begin{array}{l}\text { The false or inaccurate scientific information } \\
\text { presented in the news articles constitutes a } \\
\text { transcendent point of the whole-class debate, as } \\
\text { in Steps } 1 \text { and } 2 \text {. } \\
\text { The instructor's intervention is highly relevant in } \\
\text { promoting students' awareness of the importance } \\
\text { of thinking critically: as each group } \\
\text { communicates its decision, the instructor asks } \\
\text { open-ended questions, based on the arguments } \\
\text { produced by the undergraduates, to challenge } \\
\text { these arguments. }\end{array}$ \\
\hline 4 & $\begin{array}{l}\text { Questionnaire, Part } \\
\text { Two: Making a final } \\
\text { decision }\end{array}$ & $\begin{array}{l}\text { To conclude the debate held } \\
\text { during Step 3, each } \\
\text { undergraduate writes down his } \\
\text { or her final decision about the } \\
\text { question, "Which excerpt is } \\
\text { misleading?" }\end{array}$ & $\begin{array}{l}\text { Before this step, each undergraduate would have } \\
\text { communicated and argued his or her position } \\
\text { (once in writing during Step } 1 \text { and once orally in } \\
\text { Step 2) on the issue "Which excerpt is } \\
\text { misleading?" In addition, each small group would } \\
\text { have expressed and argued its group decision } \\
\text { (Step 3). } \\
\text { Step } 4 \text { provides the opportunity for a final } \\
\text { reflection (based on the preceding steps) to } \\
\text { encourage students' awareness of the importance } \\
\text { of thinking critically. }\end{array}$ \\
\hline
\end{tabular}

\section{The news article excerpts used in this study}

El Tiempo is a Colombian newspaper founded in 1911 that publishes information in Spanish. It is available both in printed and online format (eltiempo.com), and is the most widely read newspaper in this country (Montoya-Londoño 2014). We examined the two most read news articles of each month from the online science section from January 2016 to March 2017 (15 months). In total, we examined 30 news articles. We found false or inaccurate information in 21 of these caused by bad translation from English to Spanish and/or bad interpretation of the primary source (e.g. National Aeronautics and Space Administration (NASA), Science, the New York Times). Arguably, the person(s) who wrote these news articles have no scientific background or training. We selected three news articles to be used as the backbone of our TLS (Table 1). It is important to clarify that the primary sources: the New York. Times, NASA, 
and Science, are considered as prestigious and legitimate news media (Liang and Rousseau 2009; Robinson 2015; Shea 2015).

As part of the TLS, the instructor gave four short excerpts to the undergraduates (Step 1 in Table 1). We decided to give students only very short excerpts of the articles in which false or inaccurate scientific information was presented, as a way to help them be focus on what the activity was about. We also gave them in written form the reasons why the scientific information of each news article was considered false or inaccurate (Appendix 1). Additionally, undergraduates were allowed to use their smartphones, open the link to each article and read the whole articles online if they wanted to. Excerpts 1 and 2 came from News article 1, while Excerpts 3 and 4 came from News articles 2 and 3, respectively. Excerpts 1 and 4 present false information, and the second and the third contain inaccurate information (Appendix 1). News article 1 was published on August 15, 2016 (eltiempo.com/mundo/latinoamerica/reportaje-de-the-new-york-times-sobre-la-malaria-enlas-minas-de-venezuela-43819). In this news article, El Tiempo (secondary source) translated some paragraphs of a news article published by the New York Times (primary source) about malaria in Venezuela (nytimes.com/2016/08/15/world/venezuela-malaria-mines.html?_r=).

In Excerpt 1, El Tiempo used the term "virus" to refer to malaria. We considered this fact false information for two reasons: (1) malaria is a protozoa not a virus, and (2) the New York Times did not use the term virus. As mentioned, Excerpt 2 came from the same previous news article 1. In this excerpt, El Tiempo wrote Plasmodium Falciparum while the New York Times wrote Plasmodium falciparum. We considered this inaccurate, as in this case and according to the rules of biological nomenclature, the term "falciparum" should be written in lowercase letters as the New York Times did.

Excerpt 3 came from News article 2 published on March 21, 2017 (http:/ /www.eltiempo.com/vida/ciencia/volcan-en-marte-y-dinosaurios-en-la-tierra-habrianextinto-al-tiempo-segun-estudio-de-la-nasa-69692). In this news article, El Tiempo (secondary source) ("How does a Mars volcano relate to the extinction of dinosaurs?") changed the meaning of the headline of a news article published by NASA (primary source) ("Mars volcano, Earth's dinosaurs went extinct about the same time") (nasa.gov/feature/goddard/2017/mars-volcano-earths-dinosaurs-went-extinct-about-thesame-time). In fact, the headline published by El Tiempo can be seen as an example of what McClune and Jarman (2010) would call a "sensationalist headline". This is typical of news articles as a way to attract audiences (McClune and Jarman 2010). We considered this situation inaccurate information. One reason for this is that the headline published by El Tiempo would make (naïve) readers think that a Mars volcano caused the extinction of the Earth's dinosaurs, and thus, they might be persuaded to read this news article.

Finally, Excerpt 4 was taken from News article 3 published on September 9, 2016 (eltiempo.com/vida/ciencia/resistencia-bacteriana-a-los-antibioticos-29267). Here, El Tiempo (secondary source) makes reference to a study published in Science (primary source) about the introduction of an experimental device, Microbial Evolution and the Growth Arena (MEGA)-plate (science.sciencemag.org/content/353/6304/1147). The Science's news article states that the dimension of the antibiotic landscape used in the experiment was $120 \times 60$ centimeters. By contrast El Tiempo cited Science to say that the dimension was $122 \times 61$ centimeters. Consequently, we considered this case as false information.

As mentioned previously, Sheble (2018) considers that the information in the media is misleading when false or inaccurate scientific information is communicated. Consequently, all four excerpts are misleading because in all four false (Excerpts 1 and 4) or inaccurate (Excerpts 2 and 3) scientific statements are presented as facts. At this point, it is important to 
clarify that in our TLS (Table 1), participants did not receive instruction about the meaning of misleading information or misinformation. There are two reasons for this. First, if we gave instruction to the students about the fact that false or inaccurate information is misleading information, presumably a significant number of them would decide that all four excerpts are misleading because in all four, false or inaccurate scientific information is presented. Second, the fact that not all the students hold the same perception of misleading information is a good springboard to engage them in discussing and evaluating the false or inaccurate scientific information presented in the news articles.

\section{The thought-provoking question posed to the undergraduates}

In Step 1, undergraduates read the four excerpts (Table 1). In addition, the instructor clarified why the scientific information was considered false (Excerpts 1 and 4) or inaccurate (Excerpts 2 and 3). Critical reading and thinking as well as argumentation are crucial elements that undergraduates need to take into account in order to evaluate the implications of the false or inaccurate scientific information presented in the four news article excerpts, and produce arguments for deciding, "Which excerpt is misleading?" Possible answers were: (a) None, (b) One of the four excerpts: which one? (c) Two of the four excerpts: which two? (d) Three of the four excerpts: which three? and (e) All four excerpts.

"Which excerpt is misleading?" This is a thought-provoking question, for two reasons: (1) this question may cause classroom discussion, and (2) there could be strong (rational and reasonable) student arguments for each possible answer (Archila 2017). It should be pointed out that in this TLS (Table 1), the pieces of evidence ("Why did you make that decision?") that undergraduates may use are more important than the decisions they make about the thought-provoking question. In other words, there is no one right answer to the question.

\section{The role of the instructor}

The instructor conducted the TLS, assuming the role of a facilitator in Steps 1 and 4, and perhaps more importantly, that of a challenger in Steps 2 and 3 (Table 1). He made evaluative comments in response to the students' oral interaction as a way to help them become aware of the importance of thinking critically about wrong scientific information presented in news articles. In other words, throughout the four steps of the TLS, his sole function was to encourage the university students and engage them discussing and evaluating the false or inaccurate scientific information presented in the news articles.

\section{Method}

\section{Context and participants}

The TLS was implemented during the first (Class 1) and second (Class 2) semester of the same academic year in a university bilingual (Spanish-English) science course called: The Biology of Organisms. This course was chosen by convenience sampling (Bryman 2012). Much of the reason for this is that the second author is the course instructor. The Biology of Organisms course is a large (90-110 students per semester), introductory course that is offered every semester by the Department of Biological Sciences to participants in all undergraduate programs at a private university in Bogotá, Colombia. This university has a high academic ranking in Latin America. Its educational policy is to foster the integration of students from different majors and different age groups. Thus, it is very common to see students from different majors (not only Biology and Microbiology), and ages taking this course at the same time. 
Among the 176 eligible students, 141 (80.1\%) participated in this study. Out of these 141 participants, $73(51.8 \%)$ were females and $68(48.2 \%)$ were males. The age range was 16 to 22 years, and the average age was 18.2 years $(\mathrm{SD}=1.31)$. The authors ensured that the research respected participants' privacy. All participants were treated in accordance with the ethical guidelines of the American Psychological Association with respect to consent, confidentiality, and anonymity (the undergraduates were assigned codes to protect their privacy, for example 2U18 means class 2, undergraduate number 18).

These 141 university students were grouped into two classes. The TLS was carried out in the following order:

Class 1: Undergraduates taking Biology of Organisms during the first semester (average age 18.2 years), 73 students ( 35 females and 38 males).

Class 2: Undergraduates taking Biology of Organisms during the second semester (average age 18.3 years), 68 students (38 females and 30 males).

It is important to clarify that in both classes, the TLS was implemented at that moment of the course where the participants had the subject matter knowledge required to understand the scientific content of the four excerpts from the three news articles (Willingh am 2008). Also, they had the reading level of proficiency in English required to understand the content of the primary sources (NASA, Science, and the New York Times) (Amano et al. 2016; Archila and Truscott de Mejía 2017).

\section{Data collection}

Data were collected from written responses, and audio and video recordings. The written responses were obtained by means of a pen and paper questionnaire (Appendix 2) completed by all 141 participants in Steps 1 and 4 (Table 1), while audio and video recordings were obtained from the undergraduates' small-group debates in Step 2 and the whole-class debate in Step 3 (Table 1). Also, we recorded a conversation between the first author and each of the two classes at the end of the TLS as a way to find out their opinion about the sequence.

The questionnaire was distributed to the participants at the beginning of the TLS. The whole questionnaire was printed in Spanish (secondary source excerpts) and English (primary source excerpts); students answered in Spanish. This instrument contained the thought-provoking question ("Which excerpt is misleading?") twice. In the first part, participants were given 1015 minutes to read: (1) the four news article excerpts, (2) the reasons why the scientific information of each news article was considered false or inaccurate, and (3) make an initial decision about the thought-provoking question (Step 1 in Table 1). Each student had a copy of the text of the four excerpts (secondary and primary sources) to which he or she could refer during the TLS. In each class, during the reading time, the excerpts from the secondary source (in Spanish) and the primary source (in English) were read aloud to the whole class by four student volunteers. Then participants were given 10-15 minutes to read the excerpts independently. In the second part of the questionnaire, the students were given 5-10 minutes to make a final decision about the thought-provoking question (Step 4 in Table 1).

Six stereo digital voice recorders were randomly set up for Classes 1 (73 participants) and 2 (68 participants) in order to record the students' small-group debates in Step 2 and the wholeclass debate in Step 3. Additionally, one video camera was placed in each of the two classrooms to make a full recording of the whole implementation. Each small-group debate was conducted among two or three students who were used to working together during class activities. To receive useful feedback from the students about the implementation of our TLS, this study follows the suggestions by Archila $(2015,2017)$ and Archila, Molina, and Truscott 
de Mejía (2018a, b, c), which involves (1) generating a climate of confidence in the science classroom and (2) asking students (orally and/or through a written survey) for key points that help the researchers continuously improve the strategy. At the end of the TLS, the first author talked to the students for 10-15 minutes to find out their feed-back about each of the four TLS steps. Both audio and video recordings of the conversations with the two classes were made. Some representative students' comments are used just to better contextualize the discussion section. Most specifically, students were asked for their opinion about (1) the administration of the questionnaire (e.g. Were the excerpts easily comprehensible for you? Did you have sufficient time for reading? etc.), (2) the small-group debate and the whole-class debate (e.g. Were the debates useful for you to make a decision? Did you have sufficient time for debating? etc.), and (3) the elements they considered necessary to enable citizens to read critically science-related news articles in the twenty-first century.

\section{Data analysis}

The analysis of the data was carried out at two levels: (1) analysis of participants' evaluation of the quality of scientific information presented in the news articles, and (2) analysis of participants' awareness of the relevance of thinking critically about scientific information presented in the news articles. In response to our first research question, each participant decision was analyzed using frequency counts and percentages. In response to our second research question, we analyzed the video and audio-recordings of the episodes in which the small-group debate and the whole-class debate (Steps 2 and 3 in Table 1) took place. In accordance with verbal protocol analysis (Ruiz-Primo 2015), the episodes were transcribed verbatim and then proofread to enhance the rigor and quality of the transcriptions. The qualitative data analysis software Transana ${ }^{\circledR}$ (Mavrou, Douglas, and Lewis 2007) was used to code the transcripts. This coding was carried out according to the decisions made by participants on the evidence and arguments that they used to critique the false or inaccurate scientific information presented in the news articles. The most highly representative transcripts are commented on in the results section. These transcripts are English translations of the verbatim Spanish transcripts, care having been taken to remain as faithful as possible to the original meanings and wording.

\section{Results}

The results are presented in two sections. The first section presents the results of the questionnaire (Steps 1 and 4 in Table 1), while the second presents the results of undergraduates' engagement in small-group debate and whole-class debate (Steps 2 and 3 in Table 1).

\section{Results of undergraduates' responses to the questionnaire}

In our TLS (Table 1), initial decision (Step 1) and final decision (Step 4) were used as a way to find out how participants evaluated the quality of scientific information presented in the news articles. Basically, in Steps 1 and 4 the participants made individual decisions about the question, "Which excerpt is misleading?" As mentioned previously, there was no one right answer. There were, in fact, several possibilities given the four excerpts. Table 2 shows that in Step 1 (initial decision), in Class 1, nine possible decisions were made and in Class 2 there were ten. In Step 4 (final decision), the number of possible decisions made was lower in both classes (7 in Class 1; 8 in Class 2). It is interesting to note that the thought-provoking question led to a high level of discrepancy between participants in both classes. Arguably, there is value to be gained in terms of critical thinking if discrepancy is treated as a resource in the classroom. One reason for this is that discrepancy can be used as a springboard for promoting 
students' awareness about the importance of thinking critically through the small-group debate and the whole-class debate (Steps 2 and 3).

Table 2. Decisions made during Steps 1 and 4 and by each class.

\begin{tabular}{|c|c|c|c|c|}
\hline & Step $1(\mathrm{~N}=141)$ & $\%$ per class & Step $4(N=141)$ & $\%$ per class \\
\hline \multicolumn{5}{|l|}{ Class $1(n=73)$} \\
\hline Excerpt 1 & 5 & 7 & 10 & 14 \\
\hline Excerpt 3 & 6 & 8 & - & - \\
\hline Excerpts 1 and 2 & - & - & 1 & 1 \\
\hline Excerpts 1 and 3 & 25 & 34 & 27 & 37 \\
\hline Excerpts 1 and 4 & 3 & 4 & - & - \\
\hline Excerpts 3 and 4 & 1 & 1 & - & - \\
\hline Excerpts 1, 2, and 3 & 2 & 3 & 3 & 4 \\
\hline Excerpts 1, 2, and 4 & 2 & 3 & 1 & 1 \\
\hline Excerpts 1,3 , and 4 & 15 & 21 & 13 & 18 \\
\hline All four excerpts & 14 & 19 & 18 & 25 \\
\hline \multicolumn{5}{|l|}{ Class $2(\mathrm{n}=68)^{1}$} \\
\hline Excerpt 1 & 2 & 3 & 2 & 3 \\
\hline Excerpt 4 & 1 & 1 & - & - \\
\hline Excerpts 1 and 2 & 5 & 7 & 5 & 7 \\
\hline Excerpts 1 and 3 & 20 & 30 & 13 & 19 \\
\hline Excerpts 1 and 4 & 6 & 9 & 1 & 1 \\
\hline Excerpts 3 and 4 & 1 & 1 & - & - \\
\hline Excerpts 1, 2, and 3 & 5 & 7 & 1 & 1 \\
\hline Excerpts 1, 2, and 4 & 6 & 9 & 11 & 16 \\
\hline Excerpts 1,3 , and 4 & 5 & 7 & 8 & 12 \\
\hline All four excerpts & 17 & 25 & 27 & 40 \\
\hline
\end{tabular}

\section{Step 1-Initial decision}

As part of Step 1, the instructor gave four excerpts to the undergraduates (Appendix 1). Also, the reasons why the information was false or inaccurate were provided at the end of each excerpt. Consider the following examples to illustrate how participants used these reasons to develop their arguments, and thus, think critically about false or inaccurate scientific information presented in news articles:

[Excerpt 1 is misleading] because the distinction between viruses and protozoa does seem important to me because confusing them is also ignoring their nature, their mechanisms of action and their effects on health. On the other hand, the other three excerpts do not imply, in my opinion, any falsity or substantial inaccuracy that needs to be corrected. [In Excerpt 2] capital letters and the absence of italics are not crucial for an ordinary reader. [n Excerpt 3] the word "relationship" is sensationalist but not inaccurate. And [in Excerpt 4], to be alarmed by one or two centimeters of difference seems a little paranoid (1U50).

[Excerpts 1, 2 and 3 are misleading] because in Excerpt 1, the fact of confusing [protozoa and virus] two classes of organisms which are very different, just shows that the writer of this news article does not even investigate even a little. Excerpt 2 is misleading because that is not the correct way to write a scientific name; instead of educating readers, this news article plays the contrary role. And I think Excerpt 3 is a falsehood because it reflects the fact that the writer only cares to sell this information without considering whether the information is illogical (2U2).

[Excerpts 1 and 4 are misleading] because Excerpt 1 is communicating wrong information by publishing the claim that malaria is a virus. Excerpt 4 is also communicating wrong information because it maintains that the dimensions of the dish were bigger. In other words, this excerpt is altering the evidence of the [laboratory] procedures as well as the primary source [Science] (2U7).

These data also show that the undergraduates made different decisions. 1U50 (Excerpt 1) decided that one of the four news article excerpts was misleading, while 2U2 (Excerpts 1, 2 and 3) decided that three of them were misleading, and 2U7 (Excerpts 1 and 4) decided that only two. It should be pointed out that these examples are representative of the overall participant written responses to the question, "Why did you make this decision?" in Part One of the questionnaire (Appendix 2). That said, the examples of 1U50, 2U2, and 2U7 suggest that, independently of the decision made by each one, they used the reasons why the 
information is false or inaccurate provided at the end of each excerpt (Appendix 1) to develop their arguments when thinking critically about false or inaccurate scientific information. Additionally, these examples indicate that in this study, the question presented to participants ("Which excerpt is misleading?"), was not only (1) thought-provoking, but also (2) purposely ambiguous. These two characteristics led to a question that caused discrepancy, which is a legitimate and desirable condition for critical thinking.

\section{Step 4-Final decision}

A comparison of Steps 1 with 4 in Table 2 indicates that the number of undergraduates who decided that all four excerpts were misleading increased in Classes 1 (from 14 to 18 students) and 2 (from 17 to 27 students). This is a promising outcome; however, there is still much work to be done. Similar to the situation reported in Step 1, after the evaluation of the quality of scientific information presented in the four excerpts (Appendix 1), in Step 4, university students, in both classes, arrived individually at the same conclusion: all four present false or inaccurate scientific information. Despite the fact that there was agreement in this conclusion, they made different decisions. This trend is well illustrated in the following examples:

[Excerpts 1, 3 and 4 are misleading] Although all four excerpts communicate wrong information, Excerpt 2 is excusable because the reader gets the same idea when reading both articles [referring to El Tiempo (secondary source) and the New York Times (primary source)] [...] (1U7).

[All four excerpts are misleading] Every excerpt is misleading in its own way. I consider misleading as the fact of communicating wrong information [...] (1U22).

[Excerpts 1 and 3 are misleading] because although all four excerpts cause misinformation to the general public, the mistakes from Excerpts 4 and 2 are not so relevant $[\ldots]$ (2U14).

[All four excerpts are misleading] because all four excerpts present mistakes, although some more serious than others, the fact is that they are misleading for the reader [...] (2U49).

These examples suggest that participants' decisions about the question, "Which excerpt is misleading?" draw on their perceptions of the concept of misleading. More specifically, 1U22 and $2 \mathrm{U} 49$ considered that false or inaccurate scientific information presented in news articles may prove misleading. Consequently, they decided that, "all four excerpts are misleading". By contrast, 1U7 and 2U14 maintained that not all four excerpts' mistakes had the same seriousness (1U7) or relevance (2U14). This is the reason why 1U7 decided that "Excerpts 1, 3 and 4 are misleading" while 2U14 considered that "Excerpts 1 and 3 are misleading".

\section{Results relating to undergraduates' engagement in the small-group debate and the whole-class debate}

In our TLS (Table 1), small-group debate (Step 2) and whole-class debate (Step 3) were used as a platform to promote participants' awareness of the importance of thinking critically about scientific information presented in news articles.

Step 2-Small-group debate

Table 3 shows the decisions made by the undergraduates during the small-group debate (Step 2). As mentioned previously, each group was composed of two or three students. Hence, there were twenty-four and twenty-six small groups in Class 1 and Class 2, respectively. During Step 1 (initial decision), participants made a decision individually, and then in Step 2, they interacted in small groups to make a group decision. The reporting of each small-group debate decision marked the beginning of the whole-class debate (Step 3).

According to the results in Table 3, in Class 1, there were twenty-four groups and five different decisions. Moreover, in Class 2, there were twenty-six groups and nine different 
decisions. Similarly to the findings from Step 1 and 4 (Table 2), these outcomes suggest that the thought-provoking question caused a high level of discrepancy between small-groups in both classes.

Table 3. Decisions made during the small-group debate.

\begin{tabular}{l|l|l}
\hline Decision & Class 1 $(\mathrm{n}=24)$ & Class 2 (n $=26)$ \\
\hline Excerpt 1 & 2 & 1 \\
Excerpt 3 & 2 & - \\
Excerpts 1 and 2 & - & 2 \\
Excerpts 1 and 3 & 11 & 5 \\
Excerpts 1 and 4 & - & 2 \\
Excerpts 1, 2, and 3 & - & 1 \\
Excerpts 1, 2, and 4 & - & 1 \\
Excerpts 1, 3, and 4 & 6 & 4 \\
Excerpts 2, 3, and 4 & - & 2 \\
All four excerpts & 3 & 8 \\
\hline
\end{tabular}

The small-group debate contributed to the promotion of participants' awareness of the relevance of thinking critically about false scientific information presented in news articles. The instructor asked students to consider the importance of achieving consensus. Students highlighted the fact that the person who wrote the news article probably had no scientific background or training. This case is well illustrated in the following example from Class 1:

1U4: [Talking to $1 \mathrm{U} 3$ and 1U5] I decided Excerpts 1 and 4 were misleading because these excerpts are saying things that are not true; malaria is not a virus [referring to Excerpt 1] and the dish didn't have that measurement [referring to Excerpt 4]. Both show false information because I think the author had no scientific background.

In this example, $1 \mathrm{U} 4$ concluded that Excerpts 1 and 4 were misleading. Additionally, he/she considered the possibility that the person who wrote the article published by El Tiempo had no scientific background. Also, participants underlined the fact that a bad translation can lead to false or inaccurate scientific information. To illustrate this assertion, consider the following example:

1U31: [Talking to $1 \mathrm{U} 33$ and 1U32] It seems that the writer didn't know how to translate. I can understand that may be he wasn't a biologist. However, it is incomprehensible that he had changed the numbers [referring to $120 \times 60 \mathrm{~cm}$ in Excerpt 4].

1U33: [Talking to 1U31] I know why he [referring to El Tiempo's journalist] was wrong. He wanted to convert those numbers to feet. 4 feet equal 122 centimeters and 2 feet equal 61 centimeters.

1U32: But, why? Why did he convert it? Here [referring to the primary source: Science] was published in centimeters.

1U31: To sound more

1U33: [Interrupts] like from the United States

1U32: But, here [referring to Colombia] who knows what a foot is? No one knows what a foot is.

The preceding example indicates that $1 \mathrm{U} 31,1 \mathrm{U} 32$, and $1 \mathrm{U} 33$ were made aware of problems in Excerpt 4 and followed the instructor's instructions to think critically about the problems. $1 \mathrm{U} 31$ criticized the fact that the journalist changed $120 \times 60 \mathrm{~cm}$ (primary source: Science) to $122 \times 61 \mathrm{~cm}$ (secondary source: El Tiempo). $1 \mathrm{U} 33$ tried to find an explanation for this mistake (conversion of feet to centimeters). And $1 \mathrm{U} 32$ considered this conversion unnecessary because the primary source used centimeters which is the most common unit of measurement in Colombia. This same critique was found in Class 2 by 2S63, 2S64, and 2S65:

2U65: [...] I think this excerpt [referring to Excerpt 4] communicates inaccurate information but it isn't misleading because the margin of error is 3 centimeters and the purpose is that people 
understand the content.

2U63: But if you are going to report what Science [referring to the journal Science] published, why do you change the centimeters?

2U65: Because the journalist made a mistake.

2U63: That's wrong information.

2U64: This mistake is misleading.

\section{Step 3-Whole-class debate}

In Step 3, the instructor encouraged the whole-class debate and used university students' points of view as a springboard to promoting participants' awareness of the relevance of thinking critically about false scientific information presented in news articles. The following example is representative of the overall instructor-student interaction in Class 1:

P: Does somebody want to say something about the excerpts?

1U1: We [referring to his/her small-group] decided Excerpts 1, 3, and 4 [are misleading] because Excerpt 2 has a spelling mistake, however the reader is going to receive the same information that would be given if he read the original article [primary source: the New York Times]. By contrast, if he read Excerpts 1, 3, or 4, he is going to have a different impression from the original news. So these [referring to Excerpts 1, 3, and 4] excerpts are misleading because they are changing what the reader can say about what he is reading.

P: That analysis seems very interesting because the question is what excerpt is misleading? And what $1 \mathrm{U} 1$ is saying is that it can be seen that Plasmodium falciparum is badly written, and I think the vast majority of people do not even finish reading [...] I think people skip that [referring to Plasmodium falciparum]. [...] [1U15 raises his/her hand]

1U15: We [referring to his/her small-group] concluded that only the first excerpt is misleading because Excerpt 2 has a spelling mistake that doesn't affect communication very much. In the third one, although the headline may indicate that something is wrong, if you start to read the content [referring to the information published by El Tiempo: Excerpt 3], you can find out that it is really talking about what NASA [primary source] published.

P: [interrupts] so you [talking to 1U15] opened that link?

1U15: No

P: I ask you that because it is a good idea [opening the link].

1U15: [...] the headline [of Excerpt 3] is not the best but the news article itself is not misinforming. P: [talking to 1U15] okay, and the other [referring to Excerpt 4]? You said only the first excerpt is misleading.

1U15: Excerpt 4 presented a little mistake [...]

P: Okay [1U38 raises his/her hand].

1U38: We [referring to his/her small-group] decided that all four [excerpts] are misleading.

P: Okay.

1U38: [...] if you read these news articles and, for example, you read the scientific name in capital letters [referring to Excerpt 2], you do not realize immediately that you have that erroneous information in your mind. It is the same in the case of the numbers of the fourth [excerpt] [...] And saying that malaria is a virus causes misinformation [referring to Excerpt 1]. And in the third [excerpt], NASA is very accurate in its news, however, El Tiempo allows the reader to interpret the headline of this news item wrongly [...] [1U37 raises his/her hand]

P: [talking to $1 \mathrm{U} 37]$ Do you want to say something else?

1U37: El Tiempo is a massive news medium. There are people who will only read the headline and will get a mistaken idea.

P: That's really interesting what you [talking to $1 \mathrm{U} 37$ and 1U38] said. I'll try to discuss that point in a moment [1U70 raised his/her hand].

1U70: I'm also going to stress that the problem of the third [excerpt] is that many people only read the headline and already reach a conclusion. But it cannot be said that this article is misleading just because of that problem [...] [1U2]

${ }^{41} \mathrm{P}$ : Before giving the floor to 1U2, I would like to know how many of you usually do what $1 \mathrm{U} 37$ and $1 \mathrm{U} 70$ have just said, so who checks the web page of El Tiempo and usually reads only the news 
articles' headlines to give you an idea of what happened during the day? Raise your hands [more than one half of the class raised their hands]. I believe that what 1U37 and 1U70 say, happens to the great majority of Colombians; you read only the headlines and already you believe that you can go to take a coffee and talk with colleagues about the what is happening in the world because of reading the newspaper headlines. The problem is that [reading only the news articles' headlines] you can come to believe a number of things that are not real.

1U2: We [referring to his/her small-group] concluded that all four [excerpts] are misleading. They are practically violating the principle of journalism which is to inform and communicate information without omitting or including extra information that can cause misinformation [...] People who do not have knowledge of Biology are going to construct an erroneous interpretation and if they want to re-transmit that information, that information is going to continue to be transmitted erroneously. For us, that is a serious mistake. In the case of Excerpt 3, as we have been saying, most people's interpretations are based just on the headline. The article has nothing to do with the headline. And Excerpt 4, although the dimensions vary a few centimeters, El Tiempo also omitted the other information communicated by Science [referring to the journal Science] about the concentration of antibiotics [used in the experiment].

57 P: Okay. So you [talking to 1U2] say that when you trust El Tiempo you are supposing that this newspaper doesn't omit, doesn't change the information. In that case, the problem is that people over-estimate the truth of the information communicated in this newspaper.

1U2: Yes, this is a newspaper [referring to El Tiempo] that has to communicate information correctly $[\ldots]$

${ }^{62} \mathrm{P}$ : Yes, I think that most news media omit many things [...] Also one can see where the newspaper took the information from. You will always see sources such as EFE [referring to www.efe.com] or Reuters [referring to www.reuters.com]. El Tiempo, in my view, just translates news from other international news media. This situation can produce a problem similar to the classic telephone game: a journalist said feet [referring to Excerpt 4], another journalist made the conversion to $121.92[\mathrm{~cm}]$, and another journalist referred to $122[\mathrm{~cm}]$, and thus, the primary source changed little by little $[. .$.

This example indicates that the whole-class debate in Class 1 helped the instructor stress the importance of thinking critically about (1) news articles' headlines (line 41), (2) overestimation of the truth or certainty that can be attributed to scientific information presented in news articles (line 57), and (3) the use of primary and secondary sources (line 62). Additionally, Class 2 provides us with another example that suggests that the whole-class debate served as a learning scenario in which the instructor promoted participants' awareness of the relevance of thinking critically about false scientific information presented in news articles. Basically, this example shows that the instructor took advantage of 2U68 point of view (line 1) to promote critical reflection about the use of primary and secondary sources (line 6). He also used 2U6's opinion (line 11) to invite students to read the news articles' headlines critically (line 17) because their purpose "is to catch the attention of the reader", and thus, an inaccurate headline can cause misinformation.

1 2U68: [...] talking about Excerpt 2, suppose that I come to the Organism course [referring to The Biology of Organism course] and a classmate tells me how to write a scientific name [referring to Plasmodium falciparum], then I say that's not what my classmate told me because I read in El Tiempo that it was written in a different way [referring to Plasmodium Falciparum: term "falciparum" written in uppercase letter] [...] I suppose that news media have to be useful and reliable [...]

${ }^{6} \mathrm{P}:[\ldots]$ people say that El Tiempo doesn't produced the news [referring to Excerpt 2], the journalist does not produce this news, he cited the primary source [The New York Times] which is in English [...] if he [the journalist] is going to copy information from a primary source, he should not change [the information]. The New York Times wrote that [falciparum] in lowercase letter so why did he change this to uppercase $[\ldots]$

11 2U6: People read what's interesting for them [...] the first excerpt is wrong because of all the reasons we have already discussed. In my view, a person who is attending the Organisms course [referring to The Biology of Organism course] will consider that the second excerpt is misleading because you [talking to the instructor] taught us that this is not the way a scientific name should be written. The 
third excerpt, I think could not be judged at all because it only shows the headline and not the content as such [...] The fourth excerpt, I think doesn't give such relevant information because a centimeter makes very little difference.

${ }^{17} \mathrm{P}:[\ldots]$ 2U6 said that there is only a headline [in the Excerpt 3] and you do not really know the content of this excerpt. However, imagine I read that headline [How does a Mars volcano relate to the extinction of dinosaurs?] and I understand a Mars volcano exploded and here [on Earth] dinosaurs disappeared. And then I start to read the content of this excerpt and I realize that the headline has nothing to do with the content [...] S6 said that you decide what to read. The purpose of this headline is to catch the attention of the reader [...] [2U41 raises his/her hand]

23 2U41: It is important that this type of mistake [referring to all four excerpts] should be corrected because these could become systematic mistakes. For example, Foucault said that these systematic mistakes could respond to particular interests and promote manipulation [...] Moreover, journalists are responsible for communicating accurate information as far as possible.

Finally, it is interesting to note that the whole-class debate helped 2U41 (line 23) consider the fact that the false and inaccurate scientific information presented in all four excerpts (Appendix 1) can become "systematic mistakes" and "manipulation". 2U41's point of view reinforces the idea of using university science courses to provide undergraduates with opportunities to enrich their scientific media literacy through the evaluation of the reliability of scientific information presented in news articles as a way to foster their scientific media literacy. In line with this, at the end of the TLS, the first author asked the undergraduates about the elements they considered necessary to enable citizens to read science-related news articles critically in the twenty-first century. Elements mentioned by participants include: (1) "some scientific knowledge", (2) "considering the possibility that information can be incorrect", and (3) "questioning the primary and secondary sources". The elements mentioned by the university students corroborate those suggested by several scholars (Belova and Eilks 2016; McClune and Jarman 2010, 2011; Oliveras et al. 2013, 2014). It is interesting to note that students mentioned these elements by themselves, however, we cannot assert that our TLS was effective just because they did so. It is therefore reasonable to consider that our sequence can be a good start to show university students some of the different ways in which media information can be wrong, and thus, help them become aware of the importance of thinking critically about wrong scientific information presented in news articles.

\section{Discussion and educational implications}

In this section, the findings are discussed in terms of the specific ways in which they answer our research questions. In general, the present study described the effect of a TLS in promoting scientific media literacy in a university bilingual science course. In particular, this study aimed to answer two questions. Question 1 asked about how participants evaluate the quality of scientific information presented in news articles. First of all, an overview of the outcomes of Steps 1 and 4 (Table 2) showed that the question, "Which excerpt is misleading?" caused disagreements between participants. Our results relating to the question, "Why did you make this decision?" showed that participants evaluated the quality of scientific information presented in news articles based on their perceptions of the concept of "misleading". We consider that the fact that not all participants perceived the notion of misleading in the same way meant that they made different decisions. More specifically, students' individual written responses in Steps 1 (initial decision) and 4 (final decision) indicate that all they agreed that Excerpts 1 and 4 presented false scientific information, and Excerpts 2 and 3 communicated inaccurate scientific information. However, in Step 1, only 14 and 17 participants in Classes 1 (total of 73 students) and 2 (total of 68 students), respectively, decided that all four excerpts were misleading (Table 2). In Step 4, the number 
of students who decided that all four excerpts were misleading, increased in both classes (Class 1: from 14 to 18 students; Class 2: from 17 to 27 students).

In fact, the results from Table 2 are a contribution to recent literature on the subject of scientific media literacy that alerts to the need to create classroom scenarios in which students have the opportunity to enrich their critical views about the quality of scientific information communicated through news media (Belova and Eilks 2016; Chang Rundgren and Rundgren 2014). The implication that emerges from these results is that more science classroom activities should be created to help undergraduates deal with false and inaccurate scientific information presented in news articles. Clearly, the purpose of university science courses is not to indoctrinate students to evaluate the quality of scientific information in a specific way. Their purpose is to foster students' critical thinking about scientific information presented in news articles. Undoubtedly, critical reading activities would help undergraduates not only to realize that, sometimes, news articles intentionally or deliberately communicate false and inaccurate scientific information, but also to help them evaluate by themselves whether that information is misleading.

Secondly, in the first author's conversations with the students, the latter were asked for their opinion about the administration of the questionnaire (Appendix 2). Students commented that "time given to answer was sufficient", and that the fact that the four excerpts were read aloud to the whole class by four students volunteers, "helped them to be engaged in the activity". They also commented that the reasons why the scientific information was considered false or inaccurate provided at the end of each excerpt (Appendix 1), "were useful" and "very clear" for them. These comments reinforce the idea that university science courses should include activities that use science in the news media as a source of classroom strategies designed to provide undergraduates with opportunities to consider the importance of thinking critically about wrong scientific information presented in news articles (Lin 2014; Mysliwiec et al. 2004). The problem is that the vast majority of these university courses rarely adopt this type of strategy because of the hegemony of the Confucian model: the instructor assumes a dominant position in class and undergraduates simply memorize information. The situation becomes more complicated because very few studies have explored how to promote scientific media literacy at university level.

Question 2 asked how far the TLS were able to promote participants' awareness of the importance of thinking critically about scientific information presented in news articles. First, the results from Table 3 indicate that in both classes, the small-group debate (Step 2) led to several different decisions being made. This situation confirms the highly thought-provoking nature of the question, "Which excerpt is misleading?" Making a group decision about this question constituted a challenge that motivated undergraduates' argumentation during this deliberation stage. On the whole, the findings are consistent with the literature showing that thought-provoking questions (Andrews 2015; Archila 2018; Davies and Barnett 2015) and small-group debate (Archila 2017; Muller Mirza 2015; Mysliwiec et al. 2004; Wendland et al. 2015) can join forces to help to make university students better critical thinkers. Furthermore, students' comments offer an insight into how they engaged in critical thinking. For example, some students mentioned that the small-group debate allowed them to "improve my point of view", "evaluate others' points of view", "critique the argumentation of others", and that it serves as a way of "deepening our understanding of the scientific information" presented in all four excerpts (Appendix 2). Only in Class 2, did participants comment that "time for debating in small-group was not long enough". Clearly, these observations imply that Faculties of Science, and Education, should provide science educators with opportunities to be trained and supported in the organization of small-group debates in their university 
science courses. And possibly most importantly, science educators need to be convinced that thought-provoking questions and small-group debate are vital components for promoting critical thinking.

Additionally, some of the transcripts of the small-group debate show that this step helped students to become aware of the fact that sometimes the journalist who writes the news article has no scientific background or training. Moreover, our results suggest that smallgroup debate gave participants the opportunity to critically conclude that a bad translation or interpretation of the primary source can be the cause of false (Excerpts 1 and 4 in Appendix 2) or inaccurate (Excerpts 2 and 3 in Appendix 2) information (Amano et al. 2016; Rapp 2016). It is important to bear in mind that participants were enrolled in a university SpanishEnglish bilingual science course. That being said, in the first author's exchange with participants, they commented that "a good level of proficiency in English and critical reading" were crucial elements for thinking critically about scientific information presented in the excerpts (Appendix 1) because their primary sources (The New York Times, NASA, and Science) were written in that language. These students' comments support the claim that not having a desirable reading level of proficiency in the language of the primary source could prove an obstacle to the effective evaluation of the quality of written scientific information (Amano et al. 2016; Archila and Truscott de Mejía 2017).

Secondly, we found that the whole-class debate (Step 3), effectively served as a platform for promoting participants' awareness of the relevance of thinking critically about scientific information presented in news articles. Some of the transcripts of the whole-class debate suggest that the role of the instructor in this step was crucial. In essence, we found that he took advantage of undergraduates' opinion to not only encourage their participation, but also to help them become aware of the importance of thinking critically about scientific information presented in news articles. It may be obvious to point out that in both cases the whole-class debate contributed to the reduction of the hegemony of the Confucian model. Nonetheless, this outcome does not necessarily mean that other science educators would be interested in promoting critical thinking and redirecting their university science courses towards a new type of classroom pedagogy in which each university student plays an active role through effective and innovative class activities, such as whole-class debate. According to other scholars (e.g. Davies and Barnett 2015; Lin 2014; Sheffield Jr. 2018), the hegemony of the Confucian model is an obstacle in convincing instructors of the benefits of promoting critical thinking in their university courses. Thus, there is still much work to be done.

Thirdly, another key finding is that the two transcripts from the instructor-student argumentative interaction, presented in Step 3-Whole-class Debate section, are consistent with the literature showing that: (1) reading false or inaccurate information is an obstacle to making informed decisions (Rapp 2016), and (2) students usually over-estimate the truth or certainty that can be attributed to scientific information communicated in news articles (McClune and Jarman 2010, 2011). Moreover, certain excerpts from the transcripts of this step indicate that the instructor promoted students' awareness of the importance of thinking critically about the facts that sometimes science-related news articles (1) use sensationalist headline to attract a (naïve) audience (McClune and Jarman 2011), and (2) news media can expose people to intentional and unintentional false and/or inaccurate scientific information (Bedford 2010; Rapp 2016).

Last but not least, we created this TLS as an unfinished and open way for science educators interested in promoting undergraduates' awareness of the importance of thinking critically about wrong scientific information presented in news articles. Hence, instructors may incorporate other elements, and thus, enrich the sequence communicated in the current 
article. Clearly, our TLS starts with giving away what is wrong with the four excerpts (Appendix 2). That can be a good start to show students the different ways in which media information can be wrong (because usually they over-estimate media information). Once this is done, and if enough time is available, the instructor can give university students another article and let them formulate questions about which information seems to be missing or find false and inaccurate scientific information themselves. This could be done along learning pathways in which university science courses provide undergraduates with opportunities to be prepared for a situation in which they themselves must be alert to mistakes and misleading information.

\section{Limitations and scope for future research}

In an age of information, lifelong critical thinking as a key component of scientific media literacy is vital. Given this situation, the use of science in the news media as a source of classroom strategies designed to foster critical thinking has been tested mostly at primary, secondary and middle school level. The TLS reported here is, to our knowledge, a first documented attempt to promote university students' awareness of the importance of thinking critically about false or inaccurate scientific information presented in news articles. Although the TLS had a positive effect in Classes 1 and 2, various limitations must be noted. First of all, the biggest limitation of our study is that despite the fact that Excerpts 1 and 4 present false information, and the second and the third contain inaccurate information (Appendix 1), not all the four excerpts require a high level of critical thinking skills. This is the case of Excerpt 2 where a low level of critical thinking is required to criticize the fact that El Tiempo referred to Plasmodium Falciparum while the New York Times referred to Plasmodium falciparum. According to the rules of biological nomenclature, the term "falciparum" should be written in lowercase letters, as the New York Times did. In fact, the most correct form would be Plasmodium falciparum (in italics). In addition, a low level critique is required to evaluate the false scientific information presented in Excerpt 4, namely: El Tiempo wrote that the dimension of the antibiotic landscape used in the experiment was "122 x $61 \mathrm{~cm}$ " instead of " $120 \times 60 \mathrm{~cm}$ ", as presented by the primary source (Science). In contrast, Excerpts 1 and 3 require high critical thinking skills. Excerpt 1 shows that El Tiempo used the term "virus" to refer to malaria. A high-level critical reader would be able to evaluate this scientific information as false for two reasons: (1) malaria is a protozoa not a virus, and (2) the New York Times did not use the term virus. Similarly, a high-level critical reader would recognize that in Excerpt 3, El Tiempo used a sensationalist headline. This headline might make (naïve) readers think that a volcano on Mars caused the extinction of the Earth's dinosaurs, and thus, they would become interested in reading this news article. NASA (the primary source) used a headline that introduces the reader more accurately to the content of the news article.

Second, the false and inaccurate information selected comes only from El Tiempo. It would be interesting to evaluate the reliability of scientific information communicated in other prestigious newspapers from other countries. Third, generalizability of the current outcomes is naturally limited by the sample size involved. 141 is a relatively small number of participants. Therefore, the results and implications of our study should be considered as exploratory, preliminary, and tentative. Fourth, our analysis did not include a deep characterization of the arguments elaborated by each participant to support her/his decision. Also, another major limitation of the study is that we designed the TLS as a single 80-min class session. This is a relatively short time of implementation, although this weakness applies to nearly every study interested in tested the effectiveness of a TLS (Psillos and Kariotoglou 2016). Arguably, a longer duration would be necessary to provide more robust evidence. 
Overall, despite these limitations, our TLS has revealed many useful results, among them a way of providing university students with opportunities to become aware of the importance of thinking critically about wrong scientific information presented in news articles.

The current study provided some evidence to support the fact that science educators should purposefully integrate news-related issues into their university science courses. Thus, future research could focus on adapting the current TLS to the false and inaccurate scientific information presented in other news articles, different contexts (students of other ages, other parts of the world), and/or other university science courses (e.g. Chemistry, Geosciences, Physics). Additionally, understanding how undergraduates are influenced by false and inaccurate scientific information can inform the design of training experiences and materialsbased interventions intended to make university students better critical thinkers. Most importantly, future pedagogical strategies should be based on the premise that fostering critical thinking has received relatively little study in higher education (Davies and Barnett 2015; Lin 2014) but nevertheless is an essential aspect of scientific media literacy in contemporary life (Belova and Eilks 2016; Chang Rundgren and Rundgren 2014; Rapp 2016).

\section{Acknowledgments}

The authors would like to thank Zaide Katherine Montes Ortiz and Juan Diego Pyco Gutiérrez for their assistance in transcribing the audio recordings. Also, we would like to express our deepest appreciation to the participants who agreed to contribute to this project.

\section{References}

Amano, T., González-Varo, J. P., \& Sutherland, W. J. (2016). Languages are still a major barrier to global science. PLOS Biology, 14(12), 1-8.

Andrews, R. (2015). Critical thinking and/or argumentation in higher education. In M. Davies \& R. Barnett (Eds.), The Palgrave handbook of critical thinking in higher education (pp. 49-62). New York: Palgrave Macmillan.

Archila, P. A. (2012). La investigación en argumentación y sus implicaciones en la formación inicial de profesores de ciencias. Revista Eureka sobre Enseñanza y Divulgación de las Ciencias, 9(3), 361-375.

Archila, P. A. (2015). Using history and philosophy of science to promote students' argumentation. A teaching-learning sequence based on the discovery of oxygen. Science \& Education, 24(9), 1201-1226.

Archila, P. A. (2016). ¿Cómo formar profesores de ciencias que promuevan la argumentación?: Lo que sugieren avances actuales de investigación. Revista currículum y formación del profesorado, 20(3), 339-432.

Archila, P. A. (2017). Using drama to promote argumentation in science education: The case of "Should've". Science \& Education, 26(3-4), 345-375.

Archila, P. A. (2018). Evaluating arguments from a play about ethics in science: A study with medical learners. Argumentation, 32(1), 53-76.

Archila, P. A. \& Truscott de Mejía, A.-M. (2017). Bilingual university science courses: A questionnaire on professors' practices and espoused beliefs. International Journal of Bilingual Education and Bilingualism. https://doi.org/10.1080/13670050.2017.1334756.

Archila, P. A., Molina, J., \& Truscott de Mejía, A.-M. (2018a). Introducing undergraduates to the nature of science through the co-construction of evolutionary trees. Evidence 
from a university biology course. Research in Science Education. https://doi.org/10.1007/s11165-018-9758-z.

Archila, P. A., Molina, J., \& Truscott de Mejía, A.-M. (2018b). Using formative assessment to promote argumentation in a university bilingual science course. International Journal of Science Education, 40(13), 1669-1695.

Archila, P. A., Molina, J., \& Truscott de Mejía, A.-M. (2018c). Using bilingual written argumentation to promote undergraduates' bilingual scientific literacy: Socrative ${ }^{\circledR}$ as an immersive participation tool. International Journal of Bilingual Education and Bilingualism. https://doi.org/10.1080/13670050.2018.1522293.

Bailin, S., \& Battersby, M. (2015). Teaching critical thinking as inquiry. In M. Davies \& R. Barnett (Eds.), The Palgrave handbook of critical thinking in higher education (pp. 123-138). New York: Palgrave Macmillan.

Barnett, R. (2015). A curriculum for critical being. In M. Davies \& R. Barnett (Eds.), The Palgrave handbook of critical thinking in higher education (pp. 63-76). New York: Palgrave Macmillan.

Bedford, D. (2010). Agnotology as a teaching tool: Learning climate science by studying misinformation. Journal of Geography, 109(4), 159-165.

Belova, N., \& Eilks, I. (2016). German teachers' views on promoting scientific media literacy using advertising in the science classroom. International Journal of Science and Mathematics Education, 14(7), 1233-1254.

Bryman, A. (2012). Social research methods (4th ed.). Oxford: Oxford University Press.

Butler, H. A. (2015). Assessing critical thinking in our students. In R. Wegerif, L. Li \& J. C. Kaufman (Eds.), The Routledge international handbook of research on teaching thinking (pp. 305-314). Abingdon: Routledge.

Carver, R. B., Wiese, E. F., \& Breivik, J. (2014). Frame analysis in science education: A classroom activity for promoting media literacy and learning about genetic causation. International Journal of Science Education, Part B, 4(3), 211-239.

Chang Rundgren, S.-N., \& Rundgren, C.-J. (2014). SSI pedagogic discourse: Embracing scientific media literacy and ESD to face the multimedia world. In I. Eilks, S.Markic \& B. Ralle (Eds.), Science education research and education for sustainable development (pp. 157168). Aachen: Shaker.

Christenson, N., Gericke, N., \& Chang Rundgren, S.-N. (2017). Science and language teachers' assessment of upper secondary students' socioscientific argumentation. International Journal of Science and Mathematics Education, 15(8), 1403-1422.

Davies, M., \& Barnett, R. (Eds.). (2015). The Palgrave handbook of critical thinking in higher education. New York: Palgrave Macmillan.

Davies, M., \& Barnett, R. (2015). Introduction. In M. Davies \& R. Barnett (Eds.), The Palgrave handbook of critical thinking in higher education (pp. 1-25). New York: Palgrave Macmillan.

Ding L., Wei, X., \& Liu, X. (2016). Variations in university students' scientific reasoning skills across majors, years, and types of institutions. Research in Science Education, 46(5), 613632.

Ennis, R. H. (2015). Critical thinking: A streamlined conception. In M. Davies \& R. Barnett (Eds.), The Palgrave handbook of critical thinking in higher education (pp. 31-47). New York: Palgrave Macmillan. 
Girle, R. A. (2011). The question of the question in critical thinking? In P. Blackburn, H. van Ditmarsch, M. Manzano \& F. Soler-Toscano (Eds.), Tools for Teaching Logic. Lecture Notes in Computer Science, Vol. 6680 (pp. 93-100). Berlin: Springer-Verlag.

Golding, C. (2011). Educating for critical thinking: Thought-encouraging questions in a community of inquiry. Higher Education Research \& Development, 30(3), 357-370.

Hamby, B. (2015). Willingness to inquire: The cardinal critical thinking virtue. In M. Davies \& R. Barnett (Eds.), The Palgrave handbook of critical thinking in higher education (pp. 77-87). New York: Palgrave Macmillan.

Hastak, M., \& Mazis, M. B. (2011). Deception by implication: A typology of truthful but misleading advertising and labeling claims. Journal of Public Policy \& Marketing, 30(2), 157-167.

Hepworth, M., \& Duvigneau, S. (2013). An investigation into the development of an institutional strategy to build research capacity and information literate, critical thinking, independent learners in three African universities. In S. Kurbanoğlu, E. Grassian, D. Mizrachi, R. Catts \& S. Špiranec (Eds.), ECIL 2013 (pp. 86-92). Cham: Springer.

Hitchcock, D. (2017). On reasoning and argument. Cham: Springer.

Jarman, R., \& McClune, B. (2007). Developing scientific literacy: Using news media in the classroom. New York: Open University Press/McGraw-Hill Education.

Jiménez-Aleixandre, M. P., \& Puig, B. (2012). Argumentation, evidence evaluation and critical thinking. In B. J. Fraser, K. G. Tobin \& C. J. McRobbie (Eds.). Second international bandbook of science education (pp. 1001-1015). Dordrecht: Springer.

Jones, A. (2015). A disciplined approach to critical thinking. In M. Davies \& R. Barnett (Eds.), The Palgrave handbook of critical thinking in higher education (pp. 169-182). New York: Palgrave Macmillan.

Kahane, H. (1989). The proper subject matter for critical thinking courses. Argumentation, 3(2), 141-147.

Legates, D. R., Soon, W., Briggs, W. M., \& Monckton of Brenchley, C. (2015). Climate consensus and 'misinformation': A rejoinder to agnotology, scientific consensus, and the teaching and learning of climate change. Science \& Education, 24(3), 299-318.

Liang, L., \& Rousseau, R. (2009). Bibliometric characteristics of the journal Science: PreKoshland, Koshland and post-Koshland period. Scientometrics, 80(2), 361-374.

Lin, S.-S. (2014). Science and non-science undergraduate students' critical thinking and argumentation performance in reading a science news report. International Journal of Science and Mathematics Education, 12(5), 1023-1046.

Mavrou, K., Douglas, G., \& Lewis, A. (2007). The use of Transana as a video analysis tool in researching computer-based collaborative learning in inclusive classrooms in Cyprus. International Journal of Research \& Method in Education, 30(2), 163-178.

McClune, B. (2017). Committing curriculum time to science literacy: The benefits from science based media resources. The Journal of Emergent Science, 12, 25-40.

McClune, B., \& Jarman, R. (2010). Critical reading of science-based news reports: Establishing a knowledge, skills and attitudes framework. International Journal of Science Education, 32(6), 727-752. 
McClune, B., \& Jarman, R. (2011). From aspiration to action: A learning intentions model to promote critical engagement with science in the print-based media. Research in Science Education, 41(5), 691-710.

McLaughlin, A. C., \& McGill, A. E. (2017). Explicitly teaching critical thinking skills in a history course. Science \& Education, 26(1-2), 93-105.

Montoya-Londoño, C. (2014). In search of a model for the Colombian media system today. In M. A. Guerrero \& M. Márquez-Ramírez (Eds.), Media systems and communication policies in Latin America (pp. 66-81). New York: Palgrave Macmillan.

Muller Mirza, N. (2015). Can we learn through disagreements? A sociocultural perspective on argumentative interactions in a pedagogical setting in higher education. Teaching Innovations, 28(3), 145-166.

Mysliwiec, T. H., Shibley, I. Jr., \& Dunbar, M. E. (2004). Using newspapers to facilitate learning. Journal of College Science Teaching, 33(3), 24-28.

Oliveras, B., Márquez, C., \& Sanmartí, N. (2013). The use of newspaper articles as a tool to develop critical thinking in science classes. International Journal of Science Education, 35(6), 885-905.

Oliveras, B., Márquez, C., \& Sanmartí, N. (2014). Students' attitudes to information in the press: Critical reading of a newspaper article with scientific content. Research in Science Education, 44(4), 603-626.

Psillos, D., \& Kariotoglou, P. (2016). Theoretical issues related to designing and developing teaching-learning sequences. In D. Psillos \& P. Kariotoglou (Eds.), Iterative design of teaching-learning sequences (pp. 11-34). Dordrecht: Springer.

Rapp, D. N. (2016). The consequences of reading inaccurate information. Current Directions in Psychological Science, 25(4), 281-285.

Robinson, D. (2015). Broadcast media. In R. Gunstone (Ed.), Encyclopedia of science education (pp. 135-138). Dordrecht: Springer.

Rose, D. (2016). Data science: Create teams that ask the right questions and deliver real value. Atlanta: Apress.

Ruiz-Primo, M. A. (2015). Cognitive labs. In R. Gunstone (Ed.), Encyclopedia of science education (pp. 167-171). Dordrecht: Springer.

Shea, N. A. (2015). Examining the nexus of science communication and science education: A content analysis of genetics news articles. Journal of Research in Science Teaching, 52(3), 397-409.

Sheffield Jr, C. B. (2018). Promoting critical thinking in higher education: My experiences as the inaugural Eugene H. Fram Chair in Applied Critical Thinking at Rochester Institute of Technology. Topoi, 37(1), 155-163.

Sheble, L. (2018). Misinformation and science: Emergence, diffusion, and persistence. In B. G. Southwell, E. A. Thorson \& L. Sheble (Eds.), Misinformation and mass audiences (pp. 157-176). Austin, TX: University of Texas Press.

Thier, M. (2008). Media and science. Developing skepticism and critical thinking. Science Scope, 32(3), 20-23.

Tiruneh, D. T., De Cock, M., Weldeslassie, A. G., Elen, J., \& Janssen, R. (2017). Measuring critical thinking in physics: Development and validation of a critical thinking test in 
electricity and magnetism. International Journal of Science and Mathematics Education, 15(4), 663-682.

Wendland, M. W., Robinson, C., \& Williams, P. 2015. Thick critical thinking: Toward a new classroom pedagogy. In M. Davies \& R. Barnett (Eds.). The Palgrave handbook of critical thinking in higher education (pp. 153-168). New York: Palgrave Macmillan.

Willingham, D. T. (2008). Critical Thinking: Why Is It So Hard to Teach? Arts Education Policy Review, 109(4), 21-32.

Yung, B. (2015). Biology teacher education. In R. Gunstone (Ed.), Encyclopedia of science education (pp. 122-123). Dordrecht: Springer. 


\section{Appendix 1: Excerpts from news articles}

\section{Excerpt One}

El Tiempo (secondary source)—published on August 15, 2016

A news article published this week by the New York Times shows that watery pits of mines of the neighboring country [Venezuela] are breeding ground for the mosquito that spreads malaria.

$[\cdots]$

An important piece of information that the newspaper reports is that according to the World Health Organization, Venezuela was the first nation in the world to be certified for eradicating this virus, beating the United States and other developed countries to that milestone in 1961.

Available at: eltiempo.com/mundo/latinoamerica/reportaje-de-the-new-york-times-sobre-la-malaria-enlas-minas-de-venezuela-43819

The New York Times (primary source)—published on August 14, 2016

Venezuela was the first nation in the world to be certified by the World Health Organization for eradicating malaria in its most populated areas, beating the United States and other developed countries to that milestone in 1961.

Available at: nytimes.com/2016/08/15/world/venezuela-malaria-mines.html?_r=

False Scientific Information: El Tiempo used the term "virus" to refer to malaria. This scientific information is false for two reasons: (1) malaria is a protozoa not a virus, and (2) the New York Times did not use the term virus.

\section{Excerpt Two}

El Tiempo (secondary source)—published on August 15, 2016

A news article published this week by the New York Times shows that watery pits of mines of the neighboring country [Venezuela] are breeding ground for the mosquito that spreads malaria.

$[\cdots]$

According to this newspaper, in the first six months of the year, malaria cases increased 72 percent. Moreover, according to the "Times", "among the malaria strains present here is Plasmodium Falciparum, the parasite that causes the most fatal form of the disease"

Available at: eltiempo.com/mundo/latinoamerica/reportaje-de-the-new-york-times-sobre-la-malaria-enlas-minas-de-venezuela-43819

The New York Times (primary source)—published on August 14, 2016

In the first six months of the year, malaria cases rose 72 percent, to a total of 125,000 , according to the figures. The disease cut a wide path through the country, with cases present in more than half of its 23 states. And among the malaria strains present here is Plasmodium falciparum, the parasite that causes the most fatal form of the disease.

Available at: nytimes.com/2016/08/15/world/venezuela-malaria-mines.html?_r=

Inaccurate Scientific Information: El Tiempo referred to Plasmodium Falciparum. This scientific information is inaccurate. One reason for this is that, in this case, and according to the rules of biological nomenclature, the term "falciparum" should be written in lowercase letters as the New York Times did. The most correct form would be Plasmodium falciparum (in italics).

\section{Excerpt Three}

El Tiempo (secondary source)—published on March 21, 2017

How does a Mars volcano relate to the extinction of dinosaurs?

Available at: eltiempo.com/vida/ciencia/volcan-en-marte-y-dinosaurios-en-la-tierra-habrian-extinto-altiempo-segun-estudio-de-la-nasa-69692

NASA (primary source)—published on March 20, 2017

Mars volcano, Earth's dinosaurs went extinct about the same time. 
Available at: nasa.gov/feature/goddard/2017/mars-volcano-earths-dinosaurs-went-extinct-about-thesame-time

Inaccurate Scientific Information: El Tiempo used a sensationalist headline. This headline might make (naïve) readers think that a volcano on Mars caused the extinction of the Earth's dinosaurs, and thus, they would become interested in reading this news article. NASA used a headline that introduces the reader more accurately to the content of the news article.

\section{Excerpt Four}

El Tiempo (secondary source)—published on September 9, 2016

Scientists at Harvard University (USA) presented a model that shows the resistance of bacteria to antibiotics designed to stop or eliminate them.

For their experiment, published this Friday in Science, the researchers created a four-feet (122 centimeters) long, two-feet (61 centimeters) wide rectangular "Petri" dish with nine horizontal compartments.

Available at: eltiempo.com/vida/ciencia/resistencia-bacteriana-a-los-antibioticos-29267

Science (primary source)—published on September 9, 2016

The microbial evolution and growth arena (MEGA-plate) consists of a rectangular acrylic dish, $120 \times 60$ $\mathrm{cm}$, in which successive regions of black-colored agar containing different concentrations of antibiotics are overlaid by soft agar allowing bacterial motility.

Available at: science.sciencemag.org/content/353/6304/1147

False Scientific Information: El Tiempo wrote $122 \times 61 \mathrm{~cm}$. This scientific information is false. The reason for this is that in the primary source (Science) wrote that the dimension of the antibiotic landscape used in the experiment was $120 \times 60 \mathrm{~cm}$. 


\section{Appendix 2: Questionnaire}

\section{Part One}

Having read the primary and secondary sources of the four excerpts and the reasons to consider them as examples of false or inaccurate scientific information presented in news articles, answer the following questions.

1. In your opinion, which excerpt is misleading?

a. None.

b. One of the four excerpts: which one?

c. Two of the four excerpts: which two?

d. Three of the four excerpts: which three?

e. All four excerpts.

2. Why did you make this decision?

\section{Part Two}

After the small-group debate and the whole-class debate, answer the following questions.

3. In your opinion, which excerpt is misleading?

a. None.

b. One of the four excerpts: which one?

c. Two of the four excerpts: which two?

d. Three of the four excerpts: which three?

e. All four excerpts.

4. Why did you make this decision? 